\title{
DESENVOLVIMENTO DE FILMES COM ÁCIDO HIALURÔNICO OU ÁCIDO ASCÓRBICO PARA APLICAÇÃO COSMÉTICA
}

\section{Autores: Isadora M. B. Garros*, Roberta B. Rigon, Laura Aiello, Andréa C. P. Freitas e Gislaine R. Leonardi.}

\section{Resumo}

Filmes são estruturas formadas a partir de polímeros capazes de formar uma matriz contínua, sendo que os filmes cosméticos dissolvem-se ao serem aplicados sobre a pele úmida liberando seus componentes. Assim, este trabalho teve como objetivo o desenvolvimento de filmes cosméticos de colágeno, gelatina e quitosana, com ácido ascórbico, ou ácido hialurônico, assim como suas condições ideais de preparo e acondicionamento. Foi notada a importância da presença de umectante em uma concentração ideal para as características finais do filme. No processo de secagem a placa de silicone mostrou-se mais adequada. A temperatura de secagem na estufa de $40^{\circ} \mathrm{C}$ foi a mais eficiente. Os filmes constituidos de colágeno e quitosana foram os mais promissores e serão usados em testes futuros para avaliação da eficácia.

Palavras-chave: Filmes cosméticos, Colágeno, Gelatina, Quitosana.

\section{Introdução}

Os filmes podem ser desenvolvidos a partir de moléculas poliméricas ${ }^{1}$; os filmes cosméticos devem apresentar algumas características específicas, como a solubilidade em água ${ }^{6}$, características físico-químicas que viabilizem a liberação de ativos na pele em tempo satisfatório ${ }^{9}$, além de sensoriais atraentes para o consumidor.

Assim, este trabalho teve como objetivo o desenvolvimento de filmes cosméticos de colágeno, gelatina e quitosana, com ácido ascórbico, que é antioxidante ${ }^{4}$, hidrossolúvel ${ }^{4}$ e um ingrediente benéfico para a pele humana ou ácido hialurônico, que é um componente da matriz extracelular da derme, responsável pela firmeza, elasticidade e hidratação da pele.

\section{Resultados e Discussão}

Foram desenvolvidas 86 diferentes formulações variando-se as concentrações e tipos de umectante e polímero; assim como, suas condições de preparo e acondicionamento. As formulações foram preparadas pelo método casting, que consiste em adicionar a solução filmogênicas em recipientes rasos para que ocorra evaporação do solvente ${ }^{5}$, e armazenar em temperaturas elevadas. Foram avaliadas a exposição das formulações em duas diferentes temperaturas (25ㄴ, $45^{\circ} \mathrm{C}$ ), e em três diferentes tipos de recipientes (teflon, plástico e silicone).

As formulações foram avaliadas quanto a sua estabilidade, em triplicata, nos tempos logo após a produção (T0), após 24 horas (T24), após 15 dias (T15) e 30 dias (T30). $\mathrm{Na}$ avaliação dos parâmetros organolépticos (cor, odor e aspecto) foi utilizada a seguinte classificação: $\mathrm{N}$ (normal, sem alteração visível ou perceptível); LM (levemente modificado); M (modificado).

Foi notada a importância da presença de umectante em uma concentração ideal para as características finais do filme, como a maleabilidade e a viscosidade. No processo de secagem a placa de silicone mostrou-se mais eficiente devido a sua maleabilidade, que permite a retirada dos filmes sem interferir em sua forma. A temperatura de secagem na estufa a $40^{\circ} \mathrm{C}$ foi a mais eficiente.
Algumas formulações demostraram suscetibilidade a contaminação por fungos. Outras mostraram suscetibilidade a degradação da vitamina $C$ quando exposta a luz e a temperatura. Os filmes constituídos de colágeno e quitosana foram os mais promissores para uso cosmético e serão usados em projetos futuros para avaliação da eficácia hidratante.

\section{Agradecimentos}

Ao CNPq e a FCF-UNICAMP.

${ }^{1}$ CARVALHO, R. A. D. Desenvolvimento e caracterização de biofilmes a base de gelatina. 1998. Tese de Doutorado Faculdade de Engenharia de Alimentos, Universidade Estadual de Campinas.

${ }^{2}$ GALLARATE, M. et al. On the stability of ascorbic acid in emulsified systems for topical and cosmetic use. International Journal of Pharmaceutics, v. 188, n. 2, p. 233-241, 1999/10/25/ 1999. ISSN 0378-5173.

${ }^{3}$ LEE, D. H. et al. Improvement in skin wrinkles using a preparation containing human growth factors and hyaluronic acid serum. J Cosmet Laser Ther, v. 17, n. 1, p. 20-3, Feb 2015. ISSN 1476-4172.

${ }^{4}$ MANELA-AZULAY, M. et al. Vitamina C / Vitamin C. Anais Brasileiros de Dermatologia, n. 3, p. 265, 2003. ISSN 1806-4841.

${ }^{5}$ PARIZE, A. L.; BRIGHENTE, I. M. C.; SOUZA, T. C. R. Desenvolvimento de sistemas micro particulados e de filmes a base de quitosana e corante natural cúrcuma. 2012. (Doutorado). Físico química, Universidade Federal de Santa Catarina, Florianópolis.

${ }^{6}$ SANFELICE, A. M.; TRUITI, M. D. C. T. Produtos em filme Inovação na tecnologia de cosméticos = Film products Innovation in cosmetics technology. Acta Scientiarum: Health Sciences, Vol 32, Iss 1, Pp 61-66 (2010), n. 1, p. 61, 2010. ISSN 1679-9291

1807-8648.

Atenção: $\mathrm{O}$ arquivo não poderá ultrapassar 1 página. 